DOI: $10.51384 /$ cert-08.05

\title{
Benő EszTer
}

\section{A PRAGMATIKAI ADAPTÁCIÓ FORMÁI DÓCZI LAJOS FAUST-FORDÍTÁSÁBAN}

\begin{abstract}
Kulcsszavak: Dóczi Lajos; Faust-fordítás; honosítás és idegenités; reáliák; komparatív-kontrasztiv elemzés
\end{abstract}

\section{A PRAGMATIKAI ADAPTÁCIÓ FOGALMA}

Dóczi Lajos (született Ludwig Dux, 1845-1919) az Osztrák-Magyar Monarchia dualista államában sajtófelelősként, német és magyar lapokban publikáló újságíróként, valamint múfordítóként egyaránt a német és a magyar kultúra közötti közvetítô szerepet vállalja magára. Kétirányú müfordítói tevékenységének mintegy leképezése a két emberiségdrámának, Goethe Faustjának és Madách $A z$ ember tragédiájának átültetése. Jelen tanulmány Faust-fordításának egyik aspektusát ismerteti: hogyan jár el a német kultúrához tartozó reáliák (földrajzi, kulturális reáliák, szereplők neve, szólások, sajátos nyelvi fordulatok) átültetésekor.

A kulturális különbségek, kulturális aszimmetria leküzdésére kétféle fordítói magatartás lehetséges: a honosító és az idegenítő magatartás. Honosító fordítás esetén a fordító a célnyelvi kultúra elvárásainak igyekszik megfelelni, minimalizálja az idegenséget, kiiktatja a reáliákat, hogy a célnyelvi szöveg minél természetesebben hasson, és a célnyelvi olvasót minél kevesebb feldolgozási erőfeszítésre kényszerítse. Idegenítő fordítás esetén a fordító a forrásnyelvi kultúrához alkalmazkodik, megőrzi az eredeti idegenségét, a forrásnyelvi reáliákat, szándékosan megszegi a célnyelvi konvenciókat, és ezáltal nagyobb erőfeszítésre kényszeríti a célnyelvi olvasót. ${ }^{1}$ Egy fordítás valójában mindkét fordítói normát, a megfelelést és alkalmazkodást is alkalmazza, de mértékük különbözik, az egyik norma vezető szerepet kap. ${ }^{2}$

A honosítás különösen a színdarabok esetében érvényesül, hiszen a darabot az új közönséghez, annak kulturális hátteréhez igazítják. Ezt támasztják alá már a 18. szá-

* Benő Eszter (1973), PhD, tanár, Brassai Sámuel Elméleti Líceum, Kolozsvár, esther.beno@gmail.com.

1 Klaudy Kinga: Nyelvi és kulturális asszimetria a reáliäk forditásában = Reáliák. A lexikológiától a frazeológiáig. Értelmezések és forditási kérdések. Szerk. BÁrdosi Vilmos. Tinta, Bp., 2013. 88.

2 VÁNDOR Judit: Adaptáció és újraforditás. Fordítástudomány IX(2007). 1. sz. 40-57, 52-53. 
zad végi drámafordítások is, melyekben a leggyakoribb pragmatikai adaptáció a szereplôk nevének a magyarítása, a cselekmény helyszínének és idejének az aktualizálása. A honosításnak több fokozata van: az idegen vonatkozások teljes magyarításától azok részleges magyarításáig. ${ }^{3}$

Szinte minden szépirodalmi alkotás tartalmaz reáliákat, amelyek egy nemzeti kultúra identitásának hordozói, és majdnem minden kulturálisan kötött kifejezés döntés elé állítja a fordítót. A kultúrák közötti távolságot a fordítók több módon is áthidalhatják: magyarázó elemek betoldásával, hogy a célnyelvi olvasónak háttértudást nyújtsanak (földrajzi és történelmi reáliák esetén gyakori megoldás), lábjegyzetben hozzáfüzött magyarázattal (történelmi személyiség esetén), transzliterálás révén (a forrásnyelvi grafológiai egységet átviszik a célnyelvre), generalizálással, azaz általánosítással (az eredetinél általánosabb, tágabb értelmû́ terminussal adják vissza a forrásnyelvi szó értelmét), a reáliák kihagyásával (amennyiben azok nem hordoznak fontos információt, és nincsen különösebb érzelmi töltésük), és a reáliák átalakításával (pl. cím esetén). ${ }^{4}$

Valójában éppen a nehezen fordítható részeknél mutatkozik meg a fordító kreativitása, kompetenciája azáltal, hogy miként viszi át a célnyelvi környezetbe a nyelvspecifikus jelenségeket, az idegen kultúra elemeit, jellegzetes vonásait.

Az elemzések során a komparatív és a kontrasztív módszert használom, feltárva a forrás-, illetve célnyelvi szöveg(ek) közti hasonlóságokat, egyező vonásokat, illetve különbségeket, szembenállásokat. A Faust vizsgálata céljából egy olyan szövegkorpuszt hoztam létre, amely Dóczi Lajos (1900/1906), Komáromy Andor (1887), Szabó Mihály (1888), Palágyi Lajos (1909), Kozma Andor (1924), Franyó Zoltán (1956), Sárközi György (1956), Jékely Zoltán (1971), Márton László (1994/2016) fordításait foglalja magában. Egy-egy szövegrészlet jellemzőinek feltárásakor Efraim Israelnek [Hap Bélának] a Magyarul Bábelben internetes irodalmi antológiában megjelenített (2017/2018) Faust-fordítását is bevonom az összehasonlító vizsgálatba.

\section{A FÖLDRAJZI NEVEK ADAPTÁCIÓJA}

A Boszorkányszombat-jelenetben (Walpurgis-éji jelenetben) Mefisztó a boszorkányok találkozóhelyére viszi el Faustot, hogy Margitról elterelje a figyelmét. Ebben a jelenetben a német kultúrkör reáliáival találkozunk: a német hiedelemvilág szerint a Harz-hegység Brocken-csúcsán találkoznak a boszorkányok, a helyet Goethe pontos

3 Benő Attila: Drámafordítás és pragmatikai adaptáció = Uő: A dolgok másik neve. Komp-Press, Kvár, 2011. 138-142.

4 Simigné FenYő Sarolta: A forditás mint közvetités nyelvi alapjai = Uő: $A$ fordítás mint közvetités. Stúdium, Miskolc, 2006. 106-113. 
földrajzi megnevezéssel határolja körül („Harzgebirg. Gegend von Schierke und Elend”), a Harz-hegységben található továbbá az Ilsenstein-szikla is. Goethe a cselekmény idejét is megnevezi: Walpurgisnacht. Nézzük, hogyan jár el Dóczi Lajos ezekkel a reáliákkal, és elsősorban a Brocken hegycsúcsnak milyen célnyelvi megfelelőt keres.

A Walpurgis-éjben a Boszorkányok kara így énekel:

Goethe: Die Hexen zu dem Brocken ziehn,

Dóczi: Gellérthegyre mi repülünk.

Faust azt mondja Mefisztónak:

Goethe: Zum Brocken wandeln wir in der Walpurgisnacht

Dóczi: A Gellértet megmászni érdemes

Valamivel később Mefisztó igy szól Servibilishez:

Goethe: Wenn ich euch auf dem Blocksberg finde;

Dóczi: Az jó, hogy önt a Gellérten találom.

Láthatjuk, hogy a Brocken-csúcs megfelelője a célnyelvi szövegben a Gellért(hegy) lesz. Dóczi Lajos akkor is explicit módon megnevezi a földrajzi helyet, amikor Goethe csak utal rá:

Goethe: Dort sammelt sich der große Hauf

Dóczi: Gellért csúcsán összegyưlünk.

Még azon a szöveghelyen is, ahol Mefisztó 'Boszorkányhegyet' (Hexenberg) emleget, Dóczi Lajos ragaszkodik a Gellért-hegyhez:

Mefisztó: Da ich zum letztenmal den Hexenberg ersteige

Dóczi: Mert én utolszor mászom a Gellértet.

A földrajzi név az Auerbach pincéje-jelenetben is elöfordul, Goethe ezt mondatja Siebellel:

Goethe: Ein alter Bock, wenn er vom Blocksberg kehrt

Dóczi: Hogy egy vén bak a Gellért hegyirúl.

Láthatjuk, Dóczi Lajos a fordítás során nem Brocken, nem is Blocksberg néven emlegeti a hegyet, hanem Gellért, Gellérthegy, Gellért csúcsa néven. Nézzük, mi szolgál az analógia alapjául.

A német hiedelmek szerint a május elsejére virradó éjszakán, a Walpurgis-éjen, a boszorkányok találkoznak az ördöggel. Gyülekezésük, tivornyáik színhelye rendszerint egy hegytető, fő találkozási helyük a Brocken-csúcs, a Harz-hegység legmagasabb pontja, népnyelven Blocksberg. Az elnevezés a Harz-hegységen kívül Németország más vidékén is használatossá válik, elátkozott helyeket jelöl, a rossz szellemek gyülekezőhelyének lesz a neve. ${ }^{5} \mathrm{~A}$ magyar hiedelem szerint a boszorkányok a boszorkányszombatot a Gellért-hegyen tartják. A 17. században a hegy gyakran szerepel a

5 DӧмӧтӧR Sándor: Szent Gellért hegye és a boszorkányok. Tanulmányok Budapest Múltjából 7. Bp., 1939.104. 
boszorkányperekben a boszorkányok találkozási helyeként. ${ }^{6}$ Sőt, más vidékeken is „Gellért-hegyre való járásnak” nevezik a boszorkányjárást. ${ }^{7}$ A Budán nagy számban élő németség saját hiedelemvilágából eredően Blocksbergnek nevezi el a Gellért-hegyet, hiszen „a folyóba kikönyöklő sziklatömeg” már alakjánál fogva is a Harz-hegység Brocken-hegyére emlékezti a németajkú lakosságot - véli Dömötör Sándor. ${ }^{8}$

Valójában egy földrajzi reáliával van itt dolgunk. A Blocksberget a német-magyar elektronikus szótár boszorkányhegynek fordítja, Halász Előd Német-magyar szótára így értelmezi: „boszorkányhittel kapcsolatos gyakori népies hegynév, pl. a Brocken és a budai Gellérthegy". ${ }^{9}$ Dóczi Lajos tehát a honosítás eljárásával él, a magyar olvasó hiedelemvilágához, ismereteihez igazodik, és áthelyezi a helyszínt magyar területre. Nem véletlenül, az analógia alapjául a német lakosság által használt földrajzi név szolgál, a Budán élő német lakosság pedig Blocksbergnek hívja a Gellért-hegyet.

A további vizsgált fordításokban az adaptáció más formáit is látjuk érvényesülni:

Dóczi: Gellérthegyre mi repúlünk.

Komáromy: Gellértre tart fel a boszorka kar.

Szabó: Gellértre vonúl a boszorka.

Palágyi: Megyünk a Brocken-hegy ormára

Kozma Andor: A bércre tart a boszorka nép

Jékely: Boszorka, a Bakhegyre méssz

Franyó: Boszorka száll ki szerteszét (eltûnik a név)

Sárközi: Boszorkák szállnak fölfelé (eltünik a név)

Márton: Boszorkány Brocken-hegyre tartó

(Boszorkányok kara)
Dóczi: A Gellértet megmászni érdemes

Komáromy: Walpurg éjjel a Gellértre jövünk.

Szabó: Hogy Szentgyörgy éjén a Gellértre jöttünk

Palágyi: A Brocken-hegyre hát azért indultunk

Kozma Andor: Boszorkajárta hegy

Walpurgis-éjibe,

Jékely: avégett kaptatunk boszorkányszombaton,

Franyó: A Brockent mászva meg

Walpurgis éjjelen

Sárközi: Hegycsúcsra nyargalunk boszorkányszombaton

Márton: A Brockenra megyünk

Walpurgis-éjszakán

(Faust)

6 Uo. 93.

7 Uo. 95.

8 Uo. 104.

9 Német-magyar szótár. I-II. Szerk. HaLÁsz Előd. Akadémiai, Bp., 1994. 374. 
Dóczi: Az jó, hogy önt a Gellérten találom

Komáromy: A Gellérthegy éppen neked való

Szabó: Helyes, hogy Önt a Gellérten lelem

Palágyi: Jó, hogy itt látom a Brocken begyén

Kozma Andor: Hogy téged is a banyabércen lellek,

Jékely: Be szép, hogy a Banyák hegyén talállak!

Franyó: Boszorka-bércen vertetek ti sátrat,

Sárközi: Nagyon helyes, hogy itt talállak.

Márton: Jó, hogy itt látlak a Gellérthegyen!

(Mefisztó)
Dóczi: Hogy egy vén bak a Gellért hegyirül

Komáromy: Vén kecskebak, Gellértről hazatérve

Szabó: A Gellértről jöttiben a bakkecske

Palágyi: Vén bak, ha jő boszorkányok körébül (eltűnik a név)

Kozma Andor: S egy vén bak, jártas a

Banyahegyen.

Jékely: Vén bak, mely járt a Szent Gellértbegyén

Franyó: Egy vén bak, ott a Boszorkányhegyen.

Márton: Éjfélkor a Gellért-hegyről loholt. (Auerbach pincéje)

Ahol Mefisztó Boszorkányhegyet (Hexenberg) emleget, úgy tűnik, nem csak Dóczi Lajos ragaszkodik a Gellért-hegy földrajzi megnevezéshez:

Dóczi: Mert én utolszor mászom a Gellértet

Komáromy: Ma mászom a Gellérthegyet utoljára

Szabó: Ma a Gellértet utoljára mászom

Palágyi: Most, hogy utolszór e tetôre térek,

Kozma Andor: Boszorkányhegyre én ma legutólszor hágok;

Jékely: hisz a banyák hegyén ma mászom utoljára

Franyó: Utolszor mászom én boszorkák hegyfokára.

Sárközi: Hisz utólszor kúszok boszorkányok hegyére

Márton: Fülem a boszorkány-zsivajt utolszor hallja (eltűnik a név)

Hogyha a kiemelt szövegrészletekben megnézzük, hogyan jár el a többi fordító, azt látjuk, hogy Dóczi Lajos két kortársa - Komáromy Andor és Szabó Mihály hozzá hasonlóan adaptálja a földrajzi nevet. A Dóczi Lajosét követő, de mégis két évtizedes időbeli távolsággal, 1924-ben megjelent Palágyi-fordítás már a német Brocken földrajzi nevet használja. A későbbi fordítások vagy megőrzik (Brocken), vagy kihagyják a forrásnyelvi szövegben szereplő földrajzi tulajdonnevet. Többnyire ők is egyfajta honosítással, az általánosító fordítással élnek, földrajzi közneveket alkalmazniak: a 'Brocken' úgy jelenik meg, mint „tető”, „bérc”, „banyabérc”, „boszor- 
kajárta hegy”, „boszorkák hegye”, „boszorkák hegyfoka”, vagy magyaros tulajdonneveket alkotnak: „Banyák hegye”, „Boszorka-bérc”, „Bakhegy”. Tehát a földrajzi név vagy köznévvé válik, vagy pedig tulajdonnévként jelenik meg, mindkét esetben magyarázó, explicitáló jelleggel bír, a földrajzi helyet mint a boszorkányok, banyák hegyét nevezi meg.

A „Gellért-hegy” megnevezés elvétve a későbbi fordítóknál is előfordul, de nem alkalmazzák következetesen: Jékely Zoltán „Szent Gellért-hegy”-nek fordítja egy alkalommal, Márton László hol a német földrajzi nevet, hol pedig a Gellért-hegyet szerepelteti. Az eredeti német földrajzi nevet (Brocken) Palágyi Lajos, Márton László, egy alkalommal pedig Franyó Zoltán is beleírja fordításába.

A Walpurgis-éji jelenet elején a német eredetiben ott áll a pontos földrajzi megnevezés: „Walpurgisnacht. Harzgebirg. Gegend von Schierke und Elend”, amelyben Schierke és Elend a Harz-hegység lábánál fekvő két helység neve. Mivel Dóczi Lajos Gellért-hegyet szerepeltet a fordításában, és eltekint attól, hogy a Harz-hegységnél játszódnak az események, a pontos földrajzi megjelölést is elhagyja, a jelenet elején csupán ennyi áll: „Hegyvidék. Walpurgis éjszakája” ${ }^{10}$ Dóczi Lajos magyarítja a hegy nevét, nem tájolja be pontosan földrajzilag a helyet, ugyanakkor megőrzi a német nyelvterületen használatos „Walpurgis éjszakája” megnevezést, bár ennek a magyar kultúrában Szent György napja a megfelelője.

Nézzük meg Komáromy Andor és Szabó Mihály eljárását, akik szintén a „Gellért-hegy" földrajzi név mellett döntenek a fordítás során:

Komáromy: Walpurg éjjele. A Harchegység Schierke és Elend közt.

Szabó: Szentgyörgy éje. Hegyvidék.

Láthatjuk, egyedül Szabó Mihály nevezi „Szentgyörgy éjé”-nek a boszorkánytalálkozó idejét. Akárcsak Dóczi Lajos, ő is elhagyja a földrajzi hely pontos megnevezését.

A következő földrajzi reália a Harz-hegységben található Ilsenstein-szikla, ez Dóczi Lajos magyarításában „Örzse szirtje” lesz:

\section{Übern Ilsenstein!}

Da guckt ich der Eule

ins Nest hinein,

Die macht ein Paar Augen!
Megtekintém

Bagoly fészkét

Örzse szirtén.

Hogy' nézett!

10 Faust. Göthe tragédiája. Magyarra ford. Dóczi Lajos. Ráth Mór, Pest, 1873 (a továbbiakban Faust). 
Az Örzse a régi, gyakori Erzsébet név becéző alakja. Rokon neve az Ilze, amely német rövidülésből származik (Elisabeth > Ilse). ${ }^{11}$ Dóczi Lajos tehát nem alaptalanul magyarítja az Ilsenstein-sziklát „Örzse-szirt”-nek. Szabó Mihály Dóczi Lajoshoz hasonlóan magyarít, átültetésében „Erzsókszirt” szerepel. Franyó Zoltán szintén honosító eljárással „Ilza-kövé”-nek nevezi a sziklát. Komáromy Andor „Ilsenkő” néven említi. Az „Ilsenstein” német nevet Palágyi Lajos, valamint a további fordítók megőrzik.

Láthatjuk, hogy a földrajzi reáliák esetében Dóczi Lajos a honosítást választja. A korabeli kritika hevesen reagál rá. Dóczi Lajos 1873-ban megjelent Faust-fordításáról Závodszky Károly a Figyelóben két részletben nyilatkozik. Az első részben a fordítás magyartalanságát, a másodikban pedig a fordítónak a germán mitológiában való jártassága hiányát rója fel. Závodszky Károly így vélekedik: „... mert a jelenet címében Göthe egyenesen felirta: Harzgebirg, Gegend von Schierke und Elend, mely két falu a Brocken lábánál, mintegy harmadfél órai távolságban fekszik a csúcstól: és Dóczi mégis Gellérthegyet szerepeltet. Ezért: vagy nincs a német hitregetanban kellő ismerete, vagy szándékosan hamisította meg e helyeket. Mert ne mondja nekünk senki, hogy Dóczi a magyar nép tudalmával akarta összhangba hozni, hogy meséinkben a Gellért ismeretes. Ez a kifogás tekintetbe nem jöhet. Hiszen akkor a svéd, a francia, a skót mind helyezze által a színhelyet a maga hegyére!”. ${ }^{12}$

Závodszky úgy véli, Dóczi Lajosnak „nemcsak Gellértnek nem szabad vala fordítania a Blocksberget, hanem ha Blocksbergnek hagyja, meg kelle magyaráznia, hogy ez nem a mi Blocksbergünk". ${ }^{13}$ A magyarítás kapcsán azt is a szemére veti, hogy „iparkodik minden áron tősgyökeres magyar lenni”. ${ }^{14}$

Hogy Závodszky Károly mennyire elveti az adaptációt mint fordítói eljárást, mutatja az is, hogy ferdítésnek, meghamisításnak, akár „vaskos tudatlanságnak” tartja a honosítást Dóczi Lajos részéről: „A Faust-monda tökéletesen német, s Faust, bár a kutató, a magasra törő szellem örökemberi megszemélyesítője, mégis német; az honára, származására, műveltségére nézve. A mi az ő és a Mefisztó szavaiból, tetteiből, utaiból a mythologia körébe tartozik: az a német mythologia határai közt esik. A német mythologiában gyökereznek a fogalmak, kifejezések, melyeket más mythologia birodalmába vonni csak vastag tudatlanság vagy gyönge ítélóképesség mellett lehet. Válassza ki Dóczi Lajos, a melyik hiúságának jobban hizeleg...”. ${ }^{15}$

11 Fercsik Erzsébet-RaÁtz Judit: Keresztnevek enciklopédiája. A leggyakoribb nöi és férfinevek. Tinta, Bp., 2009. 358.

12 Závodszky Károly: Faust. II. rész. Göthe tragédiája. Magyarra ford. Dóczi Lajos. Pest, 1873. Kiadja Ráth Mór. Figyelő III(1873). 11 sz. 126.

13 Uo.

14 Uo. 127.

15 Uo. 125. 
Dóczi megoldása nem tudatlanságából vagy a mitológiában való járatlanságából következik, hanem tudatos fordítói eljárás: kulturális átültetéssel, azaz pragmatikai adaptációval van dolgunk. Ôt a honosítási szándék vezérli. A cselekményt célnyelvi környezetbe helyezi át, hogy közelebb hozza a magyar (olvasó)közönséghez a forrásnyelvi szöveget. Ez a honosítási eljárás szinte normatív jellegú a 19. századi magyar fordításokban, különösen a drámafordításokban. ${ }^{16}$ Ugyanakkor a magyarítás ötlete akár ösztönösen is felmerülhet benne, hiszen otthonosan mozog mindkét kultúrában. A célnyelvi közönség feltételezett valóságismeretéhez alkalmazkodó múfordító egyéni döntése ez, amelyet a mû világa tesz lehetővé, hiszen, amint a német mitológiában a Brocken a boszorkányok fó találkozási helye, úgy a magyar hiedelemvilágban a Gellért-hegy is az.

Az első, 1873-as fordításban Závodszky Károly talál még egy kivetnivalót: a német Rippach falunak „Ripacs”-ra fordítását. Bár alapvetően az átdolgozott kiadást (1900) vizsgálom, amelyben már „Rippach” szerepel, kitérek Dóczi Lajos korábbi fordítói megoldására. Auerbach pincéjében hangzik el Frosch szájából:

Ihr seid wohl spät von Rippach aufgebrochen.

Ripacsból későn indúlni találtak. ${ }^{17}$

Závodszky Károly a kritikájában kíméletlenül támad: „Ez a Gellért-forditás sületlenség, ép olyan, mint Rippach falunak „Ripacs”-ra változtatása. Mikor a „Gellért” szemembe ötlött legelőször, és utána legottan „Ripacs”-ot olvastam, tudva, hogy Rippach Lipcséhez közel esik, azonnal fali térképemhez siettem, megnézni, ha vajon nincs-e a liptómegyei Lipcse mellett hasonnevű község, nem tétetett-e át a Faustmonda teljesen magyar talajra? Nem találtam. Tehát ez mégis az a Rippach, mely Lipcse és Weissenfels közt az utolsó postaállomás volt...". ${ }^{18}$ Talán nem is olyan nagy „sületlenség” vagy melléfogás a név magyarítása, amely egyben beszélő név lesz, hiszen más fordítók is megteszik azt. Legfeljebb a „ripacs” fogalom stílusértéke szúrja a szemünket. Nézzük a további 19. századi fordításokat:

Komáromy: Talán Rüpókfalvából jöttetek

Szabó: Tán Kutyabonton jobbat iddogáltak?

Komáromy Andor és Szabó Mihály is magyarítja a helységnevet. Láthatjuk, hogy Dóczi Lajos fordítói változatának van egy többlete: hangalakilag közel áll az eredetihez: Rippach - Ripacs. De a későbbi fordítók sorában is van, aki adaptációval él: a helységnév Kozma Andornál „Csap” Jékely és Sárközi fordításában „Rátót”:

Kozma: Tán Csapról utra későn keltetek ti?

Jékely: Rátótról későn kerekedtetek fel?

Sárközi: Rátótról későn indultak ma, látjuk.

16 BENő: i.m. 89.

17 Faust. 88.

18 Závodszky: i. m. 126. 
A földrajzi neveknél maradva, vizsgáljuk meg a Prater magyarra fordítását. Mefisztó így szól Servibilishez a Walpurgis-éji jelenet végén:

Komm doch das Hügelchen heran, Hier ist's so lustig wie im Prater. Und hat man mir's nicht angetan, So seh ich wahrlich ein Theater.
E dombra jer! Itt víg a nép,

Egész városligeti kép.

S mit látok itt? Ha nem káprázat, Valóságos, igaz színházat.

A Prater a bécsi Prátert, a vidámparkot idézi, amely valójában egy folyóparti liget, ahova a nép mulatság végett szokott kirándulni. A Prater név feltehetőleg a latin „pratum” ('mező', 'rét'), illetve az olasz „prato” ('liget') szóból származik. ${ }^{19}$ Dóczi Lajos itt általánosító fordítással él, így lesz a német tulajdonnév-értékú Prater „városliget”. Kozma Andor „népkertbéli vígasságot” lát, Komáromy Andor és Franyó Zoltán „népkert”-nek fordítja („Ott, mint a népkertben, van élet”, Franyó), Szabó Mihály és Palágyi Lajos a „liget” szót használják. Meghagyva a tulajdonnevet, „Práter”-nek fordítja Jékely Zoltán, Sárközi György és Márton László.

Láthatjuk, a földrajzi nevek fordításakor rendszerint a honosítás szándéka - mai műszóval a pragmatikai adaptáció - vezérli Dóczi Lajos fordítói döntéseit. A Brocken vagy Gellért-hegy analóg kultúraspecifikus fogalom esetében is az adaptációt választja.

\section{A SZEMÉLYNEVEK ÉS BESZÉLŐ NEVEK FORDÍTÁSA}

A következőkben azt vizsgálom, milyen fordítói eljárást alkalmaz Dóczi Lajos a személynevek esetében. Mefisztó neve Mephisto lesz, az eredeti Mephistopheles rövidített változata. Dóczi Lajos megőrzi az idegen írásformát. Faust és Wagner, valamint az Auerbach pincéje-jelenet szereplőinek (Siebel, Frosch, Brander, Altmayer) nevénél Dóczi Lajos átvitellel él, a tulajdonneveket változatlanul átviszi a célnyelvi szövegbe.

Ahol a német névnek magyar megfelelője van, a behelyettesítést választja: így lesz Margerete Margit, Marthe Márta, Valentin pedig Bálint. A kútnál-jelenetben Margit (Gretchen) és Lidi (Lieschen) a megesett Borcsáról (Bärbelchen) beszélgetnek. Lidi Zsuzsikától (Sibylle) hallotta a hírt, és megosztja Margittal. Dóczi Lajos tehát a népies, többnyire becéző alakú nevekkel magyarosít. A személynevek hangulata így megfelel a magyar népi világnak, és hatásában közel áll az eredeti mú népies hangulatához. Az egyszerú, nép sorából való személyek nevének szónévfunkciója lesz, és konnotatív jelentéssel bővül. A szereplők magyarrá formálódnak nyelvezetük által is, beszédsajátosságaik tükrözik valamely társadalmi réteghez tartozásukat.

19 Boris Paraschkewow: Wörter und Namen gleicher Herkunft und Struktur: Lexikon etymologischer Dubletten im Deutschen. Walter de Gruyter, Berlin/New York, 2004. 276. 
A későbbi fordítók ugyancsak honosító eljárással élnek, kisebb eltérésekkel. Míg Dóczi Lajosnál Lieschen magyar neve Lidi, Bärbelchen neve Borcsa, Komáromy Andornál Liza és Boris, Szabó Mihálynál Örzsi és Borcsa név szerepel. Palágyi Lajosnál és később Kozma Andornál is Erzsi és Borcsa, Jékely Zoltánnál Lizi és Bora, Sárközi Györgynél Lizi és Borka, Franyó Zoltánnál Erzsi és Boris, Márton Lászlónál Liza és Boriska név szerepel.

A megesett lány történetét Sibylle mondta el Lidinek - ezt az idegenül hangzó nevet már kevesebben magyarosítják. Dóczi Lajos Zsuzsika névvel illeti Sibyllét. A müfordítók közül Szabó Mihály Sárának, Kozma Andor Ilusnak fordítja, de a többi fordító megőrzi a név idegenségét, esetleg magyar írásformát és hangalakot kölcsönöz a névnek (Komáromy Sibilla, Palágyi Sibylle, Jékely, Franyó: Szibill, Sárközi: Szibilla, Márton: Sibylla).

Az idegen nevek magyar ekvivalenssel való helyettesítése, magyarosítása, különösen a keresztneveké a 19. század nemzeti törekvéseinek velejárója. A 20. század folyamán válik általánossá az idegen nevek megtartása: fordításkor meghagyják a nevek eredeti alakját, ahogyan azt a forrásnyelvi nyelvközösség jelöli. ${ }^{20}$ Efraim Israel $M a-$ gyarul Bábelben irodalmi internetes antológiában megjelenített Faust-fordításában már teljes átvitelt alkalmaz a tulajdonnevek esetében. Megőrizve minden egyes név idegen alakját, Efraim Israel fordítói változatában a Dóczi Lajos honosította sor („Lidi: Hallottad már a Borcsa dolgát?”) így jelenik meg: „Lieschen: „A Bärbelchenről tudsz-e hírt?«" ${ }^{21}$

A következőkben olyan tulajdonnevek, beszélő nevek fordítását követem figyelemmel, amelyek sajátos konnotációval, közszói jelentéssel rendelkeznek. A Boszorkányszombat-jelenetben előfordul a „Junker Voland” megnevezés, melyben a „Voland” az ördög egyik középkori német neve (középfelnémet: vâlant), de a név használata szokatlan, ritka a német nyelvben (Vö. Deutsches Wörterbuch von Jacob Grimm und Wilhelm Grimm). ${ }^{22}$ Dóczi Lajos Ármány úrfi néven említi. A Czuczor-Fogarasiféle szótár a következőket írja az „ármány” szóról: „Ôseink által a pogány hittel behozott régi szó, mely gonosz szellemet, ártalmas istent jelent, ki minden jót gátolni törekszik." Dóczi Lajos fordításában az'ármány' a sátánnak azt a tulajdonságát emeli ki, amely a Faustban önmeghatározásként hangzik el: ,egy darabka oly erő, mely csak a

20 Farkas Tamás: A tulajdonnevek forditásának alapkérdéseiról. Diadal vagy Viktória, Eugén vagy Jenó? Fordítástudomány XI(2009). 2. sz. 31.

21 https://www.magyarulbabelben.net/works/de/Goethe\%2C_Johann_Wolfgang_von/Faust_(1.2.2.)_Der_Tragödie_erster_Teil._Am_Brunnen (Utolsó megtekintés: 2018. 06. 28.)

22 Jacob und Wilhelm Grimm: Deutsches Worterbuch. 16 Bde. in 32 Teilbänden. Leipzig 1854-1961. Quellenverzeichnis Leipzig 1971. Online-Version vom 28. 06. 2018. Bd. 26. 
rosszra tör...”, azaz ártani kíván. Ugyanakkor az „ármány” régi szó a magyar nyelvben, akárcsak a németben a „Voland”.

Goethe: Platz! Junker Voland kommt. Platz! süßer Pöbel, Platz!

Dóczi: Hó! Ármány úrfi jön! Helyet, gyöngy söpredék! (Mephisto)

Dóczi Lajos és Szabó Mihály választása alig tér el egymástól: Szabó egyszerūen Ármánynak nevezi a sátánt („Urad jön, Ármány jön! Tágúlj csak édes népem!”). A Faust további fordítói „Sátán úrf” (Jékely, Franyó), „Sátán ficsúr” (Kozma) néven emlegetik az ördögöt, vagy megőrzik az idegen Voland nevet (Komáromy, Palágyi, Márton).

Kozma: Helyet! csürhém, helyet! Sátán ficsúr vagyok!

Jékely: Sátán úrfi vagyok! Szép pereputty, helyet!

Franyó: A Sátán úrfi jön! Helyet, szép csőcselék!

Komáromy: Helyet! Jön Voland úr! Adj helyet csőcselékem!

Palágyi: Helyet, ha mondom! Voland urfi jön.

Márton: Helyet, jónép! Én vagyok itt, Voland!

Efraim: Voland úr jön! Helyet, te édes csőcselék!

Láthatjuk, Dóczi Lajos a honosítást választja, akárcsak Kozma, Jékely vagy Franyó. Dóczi fordítói megoldása nem szokványos, de találó jellege miatt kiemelkedik a fordítások sorából.

Az eredeti múben az ördög egy harmadik nevével is találkozunk: „Urian”. Nem honosító, hanem idegenítő eljárással él Dóczi Lajos, amikor az Urian név esetében megőrzi az idegenszerűséget: „Gellért csúcsán összegyülűnk/ Elől, felől Urián”. („Dort sammelt sich der große Hauf,/ Herr Urian sitzt oben auf.”). A „Herr Urian” a német nyelvben szintén az ördög megnevezésére szolgáló, több irodalmi múben előforduló, tréfás, megszépítő jellegű név. ${ }^{23} \mathrm{~A}$ további fordítók is megőrzik az idegen nyelvi formát.

Hogyan jár el Dóczi Lajos a beszélő nevekkel, mint a „Herr Hans” vagy „Hans Liederlich"? A Hans a németben gyakran a beszélő nevek elemeként fordul elö, egyik jelentése 'ördög' (Hans Urian), a Hans Liederlich szókapcsolatban pedig 'csavargó, züllött fickó'. ${ }^{24}$ Auerbach pincéjében hangzik el Frosch szájából a kérdéspár:

Ihr seid wohl spät von Rippach aufgebrochen?

Habt ihr mit Herren Hans noch erst zu Fa Jankó úrral vacsoráltak?

Nacht gespeist?

23 Johann Georg Krünitz-Johann Christoph Adelung: Eintrag in der Oeconomischen Encyclopädie von Grammatisch-kritisches Wörterbuch der hochdeutschen Mundart. Bd. 4. Leipzig, 1801, s. v. Der Urian.

24 HaLÁsz: i. m. 930. 
Dóczi Lajos „Fa Jankó úr” -nak fordítja a Herr Hans megnevezést: a „fajankó” gúnynévből alkot leleményesen tulajdonnevet. Dóczi Lajos megoldását Kozma Andor, Sárközi György és Franyó Zoltán is átveszi, ami arra enged következtetni, hogy a későbbi fordítók is találónak érzik a megfeleltetést. Herr Hans Komáromy Andor fordításában Rüpők Jankó urr, Szabó Mihálynál Oktondi Úr, Palágyinál Tökfilkó uir, Jékelynél Istók bácsi, Márton Lászlónál pedig Seggfej bácsi lesz, és Efraim Israel Báró Hans von Ülepp néven emlegeti. Úgy vélem, a két utóbbi megoldás az előzőek finom iróniájához képest nyersnek, illetve kissé művinek, erőltetettnek hat.

Az Utca-jelenetben Mefisztó a Hans Liederlich ('csavargó, züllött fickó') elnevezéssel illeti Faustot, aki a Boszorkánykonyha tükrében megpillantva Margitot, beleszeret a lányba. Faust egyetlen vágya a „kis teremtést elszédíteni”. Mefisztó csillapítani próbálja őt:

Du sprichst ja wie Hans Liederlich, Der begehrt jede liebe Blum für sich.
Hisz úgy beszélsz, mint Korhely Miska Ki minden rózsát tépeget.

Dóczi Lajos a forrásnyelvi szöveghez húen beszélő névvel illeti Faustot. A „Korhely Miska” név előtagjában a „korhely” német eredetű jövevényszó, a rosszalló, szidalmazó értelemben használatos „korhely” jelző annyit tesz, mint 'mulatozó, léha, duhaj, züllött', 25 'korcsmázó, iszákos, dorbézoló, henyélő, tunya, semmirevaló, kicsapongó. ${ }^{26}$ Dóczi Lajos választását találónak érzem: a választott „korhely” jelző utal Faust kicsapongására, léhaságára, ugyanakkor nem túl erős, mint némely további fordítói megoldás.

Nézzük a további fordítói megoldásokat. Kozma Andor a „kéjzsivány”, Franyó Zoltán a „céda-fi”, Sárközi György a „kékszakáll” közszóval adja vissza a nevet. További tulajdonnevekkel illeti Faustot a többi fordító: Kujon Jani lesz a Jékely-fordításban, Efraim Israel fordításában Ledér Jenő, Szabónál Vásott Bandi, Márton László meg a Nyeles Jancsi szókapcsolattal nevezi meg. Palágyi nem tulajdonnévvel, hanem egyszerűen a „léha” jelzôvel illeti („Ej, ej, az úr milyen léha lett”). Komáromy sem tulajdonnévvel, hanem jelzővel látja el: „ledér uram”. A választott kifejezéshez mindig sajátos konnotáció, érzelmi töltés társul. A fordítói megoldásokat olvasva érzékeljük, hogy a szavak bonyolult „holdudvara” más-más árnyalatot kölcsönöz a megszólítottnak. A „kujon” kifejezés inkább nőcsábászjelleget kölcsönöz Faustnak, szinonimája

25 Etimológiai szótár. Magyar szavak és toldalékok eredete. Szerk. ZAIcz Gábor. Tinta, Bp., 2006. 434.

26 Czuczor Gergely-Fogarasi János: A magyar nyelv szótára. Emil Gusztav Magyar Akadémiai nyomdásznál, Pest, 1862. https://www.arcanum.hu/en/online-kiadvanyok/ Lexikonok-a-magyar-nyelv-szotara-czuczorfogarasi-55BEC/ (Utolsó megtekintés: 2018. 07. 01.) 
'szoknyavadász, szoknyapecér, nőbolond', ${ }^{27}$ míg a „ledér” szinonimái 'kicsapongó, könnyüvérü, csélcsap, léha, szabados'28, a „vásott” olyan személyre utal, akinek az erkölcsi érzései elvástak, a „nyeles” szó pedig a mai szleng része. ${ }^{29}$

Mefisztó megszólítását Faust megtisztelő jelzővel viszonozza: Herr Magister Lobesan.

Mein Herr Magister Lobesan, Laß Er mich mit dem Gesetz in Frieden!
Nagytiszteletú praeceptorom, Nekem itt föl ne emlegesse A törvény paragrafusát.

A „lobesan” vagy a középfelnémet „lobesam” (lat. laudabilis) kifejezés titulusokban szerepelt a Grimm-szótár ${ }^{30}$ szerint, jelentése 'dicséretes, hírneves, érdemekben gazdag, nagyérdemü'. Dóczi Lajos a „Magister”-nek a latin „praeceptor”-t felelteti meg (tanár, tanító, oktató), a „Lobesan”-nak meg a „nagytiszteletư” jelzőt („nagytiszteletű praeceptorom"). Fordítása hü, és egyben honosításnak is tekinthető.

Hadd nézzük a többi fordítói eljárást: Komáromy a „tisztelt professorom”, Szabó a „tisztelendő mesterem”, Franyó Zoltán egyszerúen a „Magiszter úr” megszólítással él, Sárközi György a „Tiszteletes tanár uram”, Palágyi a „Főtisztelendő bölcs papom” megszólítással. Kozma Andor a „Nagyképü tanár úr” megnevezéssel máris más konnotációt ad a megszólításnak (fölényes), akárcsak Jékely a „Derék erkölcsbíró uram” (másokat bírálgató) megnevezéssel. Márton László „Magiszter úr, Nagytudományú" hátravetett jelzős szerkezettel fordítja, Efraim Israel a „Jó Rendesi doktor uram" megszólítással, amely a megszokottól eltérő, eredetieskedő megnevezésként hat.

Az idegenítéssel is találkozunk Dóczi Lajos Faust-fordításában. A szellemlények nevét az első Dolgozószoba-jelenetben Dóczi Lajos nem magyarosítja. Faust a sétájából tér haza; az ördög, aki fekete uszkár képében férkőzik be Faust szobájába, vándordiákká változik. Faust ekkor megjelenésre akarja kényszeríteni az ördögöt, és Salamon kulcsához (Clavicula Salomonis) fordul, a 16. századi varázslókönyvhöz, amely kaput nyit a természetfölötti világra, összeköttetést biztosít a makrokozmosszal, és hatalmat ad az elemekben rejlő szellemek fölött. Faust a „négyek mondását” veszi elő:

Salamander - villanj!

Undene - szörnyedj!

27 Magyar szókincstár. Rokon értelmü szavak, szólások és ellentétek szótára. Szerk. Kiss Gábor. Tinta, Bp., 2001. 499.

28 Uo. 513.

29 http://mek.oszk.hu/adatbazis/lexikon/phplex/lexikon/d/szleng/sz169.html. A Debreceni Egyetem Magyar Nyelvtudományi Tanszékének honlapjának szlengszótára. http:// mnytud.arts.klte.hu/szleng/szl_kut/index.php (Utolsó megtekintés: 2019. 02.04.)

30 Grimm: i.m. Online-Version vom 28.06.2018. 
Sylphe - elillanj!

Kobold - görnyedj!

A ki tudja,

Mi az útja

És mivolta

Mindenik elemnek,

Parancsolva

Szólhat a szellemseregnek.

Tünj le tüzbe,

Salamander!

Zuhogj vízbe,

Undene!

Lobogj szépen, csillagképen,

Sylphe!

Házi szolgálatra fuss,

Jöszte végül, segítségül,

Inkubus, Inkubus!

A felsorolt nevek mutatják, hogy Dóczi Lajos itt az idegenítés eszközével él, a négy szellem nevét nem magyarítja. Az idegenszerűség itt, úgy vélem, növeli a ráolvasás varázsigejellegét. Az idegenül hangzó nevek mitológiai alakok nevei: Undene (vízi szellem, sellő, undiné), Sylphe (szilfid, a levegő lénye), Salamander (szalamandra, a tüz szelleme), Kobold (manó, házi szellem), akik a négy alapelem víz, tűz, levegő, föld megtestesítői.

A kritika azonban kifogásolja az idegen nevek használatát, akárcsak a magyarázatok hiányát. Závodszky Károly már említett cikkében úgy véli, a magyarázatok hiánya miatt „sok hely élvezhetetlen”. Sőt, nem csupán a magyar, hanem a német olvasó számára is szükségesek lennének a magyarázatok, állítja. Majd így folytatja: „Mi ez a Salamon kulcsa? Dóczi nem gondol vele. Mi az a Salamander, Unde, Sylphe, Kobold? Dóczi nem értelmezi. Mi az Urián? szintén nem kommentálja. Holott e helyeket csak mythológiai ismeretek mellett méltányolhatjuk igazán, becsük és mélységük szerint". ${ }^{31}$

Nem az idegenítés, hanem a honosítás mellett dönt Jékely Zoltán, aki részben magyarítja a megszólításokat: Szalamandra, Undéne, Szilfe, Kobold szerepel a ráolvasásában. Igazán honosító eljárással Szabó Mihály él, akinek a fordításában Szalamandra, Sellő, Légtünde, Manó szerepel. Franyó Zoltán szinte teljesen Szabó Mihály mintáját követi, amikor a négy elem neve Szalamandra, Sellő, Tünde, Manó lesz célnyelvi szövegében.

31 ZÁvodszKY: i.m. 125. 
Úgy vélem, az idegenszerűség megőrzése itt jogos, esztétikai hatása van. Az akusztikai hatás fokozó jellege igézőbbé teszi a ráolvasást, amelyet Faust mond. Egy értelmetlen, idegenszerű hangcsoport könnyebben kelt hangalaki kifejezéstöbbletet, mint amelynek nincs ilyen jellegű motiváltsága. Dóczi Lajos tehát nem csupán honosító eljárással él, hanem idegenítő eljárást is alkalmaz, ahol szükségesnek találja.

\section{A KIHAGYÁS MINT ADAPTÁCIÓS ELJÁRÁS}

A honosítás egy másik válfaja a kihagyás. Ez történik Dóczi Lajos célnyelvi szövegvariánsában a „Walpurgis-éji álom avagy Oberon és Titánia aranylakodalma intermezzoja” jelenettel. A boszorkányszombat után Mefisztó továbbviszi Faustot egy Walpurgis-éji álomba, Oberon és Titánia esküvőjére. Dóczi Lajos ezt a jelenetet kihagyja, nem fordítja le magyarra. Lábjegyzetben utal rá, hogy a mủ egy része kimarad: „A Walpurgis-éjjeli álmot, mint a magyar közönség előtt teljesen érthetetlen alkalmi gúnyverset, kihagyandónak véltem, A fordító". ${ }^{32}$

A vizsgált Faust-fordítások sorában egyedül Dóczi Lajos Faust-fordításában marad el az intermezzo. Kortársai (pl. Komáromy: Walpurgéji álom vagyis Oberon és Titania aranylakodalma. Egy Intermezzó; Szabó: Szentgyörgyéji álom vagy Oberon és Titania aranymenyekzője. Játék szünet alatt), valamint a későbbi fordítók is lefordítják a jelenetet. Ez a jelenet Shakespeare Szentivánéji álom (a szereplők Titania, Puck és Oberon), valamint $A$ vihar (Ariel neve) címú múvére utal, és mindmáig kérdés, hogy Goethe miért füzte be a dráma cselekményébe ezt a nem igazán illeszkedő, zűrzavaros jelenetet.

Vitatható, hogy helyénvaló-e Dóczi Lajos adaptációja, amely mögött feltehetőleg az a szándék áll, hogy a darabot (vagy annak bizonyos vonatkozásait) a célnyelvi közönség feltételezett kulturális ismereteihez igazítsa. Mit kell megőriznie a múfordítónak, és mit lehet módosítania vagy akár kihagynia a fordításban? - tesszük fel a kérdést. Dóczi Lajos feltehetőleg azért hagyja el ezt a jelenetet, mert úgy ítéli, korának magyar közönsége számára nem ismertek Goethe kulturális utalásai. A közjátékban nincs cselekmény. Rudolf Eppelsheimer irodalomtudós szerint az álomjelenet egy zavaros kavalkád, amelyben Goethe saját kora közéleti viszonyait és a kortársait szatirizálja: irodalmárokat, tudósokat, politikusokat. Servibilis nem más, mint Karl August Böttiger dilettáns színházigazgató, Hennings pedig August Adolph von Hennings, aki Goethe verseit élesen kritizálta, Szélkakas (Windfahne) Johann Friedrich Reichardt újságíró, akit kétkulacsosnak tartottak, a Daru (Kranich) Johann Caspar Lavater lelkész, akinek a szemfényvesztést és hazudozást veti a szemére Goe-

32 Dóczi Lajos-Csengeri János: Goethe drámai múveiböl: Faust, Iphigenia Taurisban. Lampel R. Kvkeresk., Bp., [1906]. 176. 
the, a Vaskosak (Die Massiven) pedig a forradalmi tömeget képviselik - jelzi Eppelsheimer. ${ }^{33}$ Goethe maga is megjelenik, ő a Világfi (Weltkind). ${ }^{34} \mathrm{~A}$ mú azonban a jelenet nélkül is tartalmilag „egész" és élvezhető marad. Amennyiben Dóczi Lajos meghagyta volna a jelenetet, a magyar olvasó számára lépten-nyomon magyarázatokat kellett volna hozzáfüznie, ami nehézkessé tette volna a megértést. Színpadi előadás esetében pedig lehetetlen magyarázatokkal ellátni a jelenetet. Tény, hogy az amúgy éles hangú kritika a kihagyást nem rója fel a fordítónak.

\section{A MAGYAROS JELLEG ERŐSÖDÉSE KÜLÖNBÖZŐ KIFEJEZÉSEKBEN, BESZÉDHELYZETHEZ KÖTÖTT FORMULÁKBAN}

A fordítás során a tartalom hozzáidomul a célnyelv sajátos látásmódjához. A különféle reáliák a forrásnyelvi nyelvközösség kultúráját és gondolkodásmódját tükrözik, legyenek azok néprajzi, társadalmi reáliák vagy történelmi események. A múfordítónak döntenie kell, a két kultúra közötti közvetítés során mit hagy meg, illetve mit honosít. A pragmatikai adaptáción nemcsak kulturális megfeleltetést értünk, hiszen az eljárás a nyelvi megformáltság és kulturális utalások tekintetében is otthonosabbá teszi a múvet.

A kulturális átültetés egyik formája az, amikor a német kultúrára, német nyelvre való utalást a fordító felfüggeszti. Dóczi Lajos következetes a honosításban: hogyha a Gellért-hegy vidékére helyezi át a boszorkányszombat színhelyét, a 'német szó, 'német hon' kifejezéseket is elkerüli, így a „német színpad” helyett a „honi színpad”, a „szeretett német nyelvem” helyett a „szülötte szóm” kifejezést használja. A reáliák ilyen jellegú általánosító fordítása és kihagyása ma a fordítás szövegtulajdonságának tekinthető. ${ }^{35} \mathrm{Az}$ Igazgató így szól az Elōjáték a szimpadon-jelenetben:

Ihr wißt, auf unsern deutschen Bühnen Probiert ein jeder, was er mag;
Tudod, honi szinpadjainknál

Mindenki tesz, a hogy tehet.

Az ilyen jellegú honosítás nem jellemzi Dóczi Lajos kortársainak a fordítását, akik a „német színpadunk/ színpadjaink/ német színpadon” kifejezésekkel élnek

33 Rudolf Eppelsheimer: Goethes Faust. Das Drama im Doppelreich. Versuch einer Deutung im Sinne des Dichters. Verlag Freies Geistesleben, Stuttgart, 1982.161-196.

34 A magyar nevek a Jékely-fordításból származnak. Johann Wolfgang GoetrHe: Faust. Fordította: Jé Kely Zoltán. Magyar Helikon, Bp., 1971.

35 Klaudy Kinga: A fordítási univerzálékról különös tekintettel az egyszerúsitésre = A nyelv nevelő szerepe. A XI. Magyar Alkalmazott Nyelvészeti Kongresszus előadásainak válogatott gyưjiteménye. Szerk. Fóris Á. et. al. Lingua Franca Csoport, Pécs, 2002. 483. 
(Komáromy, Szabó, Palágyi). Az Újszövetség fordításának nekikezdő Faust így elmélkedik:

Mich drängt's, den Grundtext aufzuschlagen, Mit redlichem Gefühl einmal

Das heilige Original

In mein geliebtes Deutsch zu übertragen.
Vágyom kutatni ős szavát,

$\mathrm{S}$ a szent nyelvü eredetit, Mint súgja az együgyú hit, Szülötte szómba tenni át.

Komáromy Andor a következőképpen utal a nyelvre: „A szent eredetit az én szeretett / Német nyelvembe átal ültessem”. Szabó Mihály és Palágyi Lajos Dóczi Lajoshoz hasonlóan honosít: Szabónál Faust „hazám nyelvére”, Palágyinál „édes nyelvünkre" ülteti át a forrásnyelvi kifejezést.

Dóczi Lajos a sajátos megnevezéseknek magyaros kifejezéseket feleltet meg. Az Éjjel-jelenetben Faust megidézi a Földszellemet, majd Wagnerrel, a tanítványával elmélkedik. Faust úgy érzi, hogy a meglévő tudása hiábavaló, nem talál választ kérdéseire sem a tudományban, sem a mágiában. Wagner az ellentéte Faustnak, nem kínozzák kétségek, mint a mesterét. Faust arra próbálja rávezetni tanítványát, hogy az általa elsajátított és elsajátítható tudás kevés, a „múlt kor szelleme”, „egy régi bölcs szava" mind nem kielégitő:

$\mathrm{S}$ az idők szelleme? Az ám!

A tisztelt szerzők szelleme csupán,

A melyben tükröződnek az idők.

S mily torzalakká válik mindez!

Elfutnál, ha csak rá tekintesz.

Egy lomtár, egy szemétkosár még,

S hozzá legföllebb egy Vitézi Játék.

Pompás sententiákra fejtve szépen

Mint bábjaik szájába illik épen.

Faust monológját olvasva tűnik fel a Vitézi Játék szókapcsolat magyaros jellege. Dóczi Lajos újra a honosítással él, azonban fordítói megoldása nem adja vissza az eredeti iróniáját, amely a felgyülemlett emberi tudást, ismeretet elégtelennek, illuzórikusnak, talminak, csak „színpadi akciónak” tartja, amely nem ad választ az emberi lét nagy kérdéseire, megpróbáltatásaira. A német eredetiben a „Haupt- und Staatsaktion” kifejezés szerepel („Ein Kehrichtfaß und eine Rumpelkammer/ Und höchstens eine Haupt- und Staatsaktion”).

Dóczi Lajos megoldásával ellentétben Komáromy Andor és Kozma Andor szó szerint fordít:

Komáromy: Legföljebb egy-egy status actio

Kozma: S legfeljebb fó- és státusakció... 
Feltehetőleg Dóczi Lajos hatására Franyó Zoltán fordításában a „vitézi színdarab” szókapcsolatban visszaköszön a „vitézi” jelző. Szabó Mihálynál „nagy hős játék”, Palágyi Lajosnál „udvari nagy díszkomédia”, Jékely Zoltánnál „históriás színdarab” szerepel, Sárközi Györgynél „vértől csöpögő, bús tragédia”, Márton Lászlónál „színpadi akció”.

$A$ város kapuja elött zajló jelenetben színes embertömeggel találkozunk. Húsvét ünnepe van, szabadnap, különféle emberek beszélgetnek az őket foglalkoztató dolgokról. A Másik polgár (Andrer Bürger) szájából hangzanak el a következők:

Nichts Bessers weiß ich mir an Sonnund Feiertagen

Als ein Gespräch von Krieg und

Kriegsgeschrei,

Wenn binten, weit, in der Türkei,

Die Volker aufeinander schlagen.

Man steht am Fenster, trinkt sein

Gläschen aus

Und sieht den Fluß hinab die bunten

Schiffe gleiten;

Dann kehrt man abends froh nach Haus, S estére haza mék vígan, Und segnet Fried und Friedenszeiten. És áldom Istenem, hogy béke van.
Ünnepnapon csak kedvesb, mint akármi,

Igy harczról, háborúról diskurálni,

Ha messze, Isten háta megett,

Török tatárral összeveszett.

Pohárka mellől ilykor a folyót

Nézem, hogy hordja mind a kis hajót,

A figyelmes olvasónak megakad a szeme egy soron: míg a német eredetiben a messzi Törökországban egymásra törnek a népek, addig a magyar nyelvú fordításban „török” és „tatár” szerepel: „Török tatárral összeveszett”. Itt úgyszintén pragmatikai adaptációval állunk szemben, amely a magyar történelmi múlt török veszedelmét, tatárjárásait idézi. A többi Faust-fordítónál nincs szó tatárról, mint ahogy az eredetiben sem. Még két kifejezés tünik fel a részletben: a „hinten, weit, in der Türkei” ('lent, messzi Törökországban'), amelyet magyarul Dóczi Lajos „az Isten háta megett” frazeológiai szókapcsolattal ad vissza ('nagyon eldugott, távoli helyen'), fokozva ezzel a messzeséget. A „[man] segnet Fried und Friedenszeiten” ('áldjuk a békét és békeidőket') egy, beszédhelyzethez kötött pragmatikus helyzetmondat formájában szerepel Dóczinál: „áldom Istenem”. Mindkét fordítói megfeleltetés többletet hordoz, dúsítás a fordító részéről, az eredetiben nincs jelen.

Magyaros jellegű a „kutyabőr” kifejezés a második Dolgozószoba-jelenetben, ahol Mefisztó nem elégszik meg az adott szóval, írásba akarja foglalni a szerződést: pergamenre, Dóczi Lajos fordításában „kutyabőrre” óhajtja íratni. Mefisztó bagatellizálja a dolgot, mintha jelentéktelen, szimbolikus dolog volna az egész, pedig valójában Faust lelkéről van szó. 
Faust:

Faust:

Allein ein Pergament, beschrieben und beprägt, De kutyabör, viasz, meg tinta Ist ein Gespenst, vor dem sich alle scheuen.

Oly rém, melytől mindenki megriad.

A „beirt s pecsétetelt pergament” (Komáromy), „beírt pecsétes pergament” (Szabó), „irás pecsétivel” (Palágyi) „pergament” (Franyó, Sárközi), „teleírt, pecsétes ív” (Márton), „pecsétes, írt papírlap” (Jékely) helyett Dóczi Lajos a kutyabőr által a „kutyabőrös nemesség” fogalmát idézi fel az olvasóban.

Kozma Andornál és Szabó Mihálynál pár sorral lejjebb visszaköszön a „kutyabőr” kifejezés, meglehet, Dóczi Lajos hatására, hiszen a németben „Wachs und Leder”, azaz 'viasz és bőr' szerepel:

De írott pergament s pecsét, mely véle jár.

Mint a kisértet, mindenek borzalma.

A szó már elhal ott a tollban

$\mathrm{S}$ viasz- és kutyabör-uralom van.

Az elemzett megfeleltetéseknek az a fordítói elvárás állhat a hátterében, hogy a célnyelvi szövegnek úgy kell hangzania, mintha magyar szerző magyarul írta volna.

A honosítás szándéka vezérli Dóczi Lajost a népies, magyaros szavak használatában is. A 19. században kiépülő magyar nemzettudat a népi jellegzetességeket a nemzeti jelleggel azonosítja. Gyulai Pál hangsúlyozza, hogy a népnyelv alkalmas „a fenség, erő, kellem és humor kifejezésére”, de hatása az ellentétébe fordulhat, „durvasággá fajulhat”, „ha válogatás vagy ha szükséges átalakítás nélkül” használják a „népi szólásmódokat". Amennyiben az író népiesebb akar lenni a népnél, elvész a népnyelvre jellemző, „keresetlen egyszerűség” - figyelmeztet Gyulai. ${ }^{36} \mathrm{Az}$ irodalmon belül jelentkező népi-nemzeti irányzat, melynek Petőfi és Arany fő képviselője, a népiességet népnyelvi szókinccsel, népköltészeti formákkal igyekszik megvalósítani. A következő szövegrészletek szóhasználatában Dóczi Lajos is a magyar nemzeti jelleg erősítésére törekszik:

36 Gyulai Pál: Költôi nyelvünk és szépprózánk. Budapesti Szemle 89(1897). 243. sz. 485. 
Was steht ihr Weiber, heult und klagt?

Still, altes Weinfaß!

Eure Höflichkeit erfreut mich sehr

Es erben sich Gesetz' und Rechte

Wie eine ew'ge Krankheit fort

Wie hält's nur noch zusammen?

Bald hatte das arme Tier genung

Ich weiß dir so ein Schätzchen auszuspüren

Wer schlich sich ein?

O Herr, verzeiht den rohen Gruß!

Bei aller verschmähten Liebe!

Was kneipt dich denn so sehr?

Den ganzen Tag hat man die Hände voll!

Da wurden seine Geschwister

Bei Hof auch große Herrn

Auf! Holla! Ho!

A! tara lara da!
Mit óbégattok, asszonyok?

Csitt, öreg hordó!

Igen nyájas, hogy ide fáradt

A törvény s jogok öröksége

Mint ós nyavalya örökül

Mi tartja benne a szuszt még?

Doszt lesz néki nemsokára

Egy ily tubát tudok számodra én

Lopva, suttyomba?

Uram, a zokszót megbocsádd

A fitymált szerelemre!

Mi csikar annyira?

Egész nap herczehurcza, hajtás

$\mathrm{S}$ az udvarnál nagyra ment

Minden pereputtya

Haj! Tillaárom!

Hej, dinom-dánom, sanálom!

A dőlt betűvel kiemelt népies kifejezések részben hangutánzó szavak: a „Csitt!” bizalmas jellegú mondatszó; az Arany János által is réjaként alkalmazott „tillaárom”, ${ }^{37}$ a „dínom-dánom” kurjantás mint a jókedv, lelkesedés, humor kifejezője; a bizalmas jellegü, hangfestő „hercehurca”, a rosszalló, hangutánzó „óbégat”. Érzelemkifejező ereje van már hangalakjánál fogva a „suttyomban” főnévnek, a bizalmas, tréfás „szusz” fónévnek, a „doszt” határozószónak, a fölényes lebecsülést kifejező „fitymál” igének, de a „tuba” fônévnek is, amely a fiatal nő kedveskedő, népies megnevezése. Az alkalmazott népies nyelvi elemek nem csupán magyar nemzeti jelleget visznek a célnyelvi szövegbe, de ezenfelül a hangzásbeli expresszivitásukhoz kapcsolódó hangulat is növeli kifejezőerejüket. A kifejezőség fokozódik azáltal, hogy a felsorolt nyelvi elemekhez olyan nyelven kívüli elemek társulnak, mint a gesztus, a hanghordozás, a szituáció.

A kultúraspecifikus kifejezéseken kívül a reáliák sorába tartoznak a ruhadarabok is. A ruhadarabok megnevezésének a fordításakor Dóczi Lajos fordítására nemcsak a honosítás jellemző, hanem az idegenítés is. Nézzünk először példákat a honosításra. Mefisztó így szól Fausthoz:

Csak add nekem palástod, kucsmád

Komm, gib mir deinen Rock und Mütze.

37 Arany János: Irószobám = Arany János vidám versei. Szerk. R. Berde Mária. Lepage Lajos Könyvkereskedés, Kvár, 1942.13. 
A német „Rock” megfelelője 'kabát', a „Mütze” meg 'fejfedő, sapka'. Dóczi Lajos itt honosít, magyaros ruhadarabokat ad a szereplőkre.

$\mathrm{Az}$ Auerbach pincéjében énekelt bordalban (Runda) már az idegenítésnek vagyunk tanúi:

$\mathrm{Da}$, miß dem Junker Kleider

Und miß ihm Hosen an.

Und daß, so lieb sein Kopf ihm ist, Die Hosen keine Falten werfen!
Szabj ez úrfinak ruhát

Kaputot, nadrágot.

És úgy vigyázzon a fejére, Hahogy a plundra ráncot vet.

A ruhadarabok immár nem magyarosak, hanem német ruhadarabok: a „kaput” ('hosszú felsőkabát mint polgári férfiviselet') és a „plundra” ('bő szárú férfinadrág'). Hogyha a 19. századi kortárs fordítók megoldásait nézzük, láthatjuk, hogy az idegenítés Dóczi Lajosra jellemző eljárás, Komáromy Andornál és Palágyi Lajosnál egyszerűen „ruha”, „nadrág” szerepel, Szabó Mihály a „pantallon”, „kabát”, „nadrág” lexémákat választja.

A tanítvány a „pitvaron” vár Faustra, amely a tornác népies megnevezése („Most is vár - hallom - egy a pitvaron” - „Gleich hör ich einen auf dem Gange!”). Ugyanakkor Bálint rátámad Faustra, és így szól: „Ki már azzal a gyíklesốvel!”(„Heraus mit Eurem Flederwisch!"). A gyíkleső német eredetû szó, egy vékony, rövid kard gúnyneve, amelyet díszöltözethez szoktak felkötni. A „pitvar” csak Dóczi Lajosnál fordul elő, Komáromy, Szabó, Palágyi a „folyosó” lexémát választja; a kard mindhárom fordítónál „gyíkleső".

Mefisztó így szól: „De parádés napon ordót viselni illik” („Doch läßt am Galatag man seinen Orden sehn”). Az „Orden” ('rendjel') fordításakor Dóczi Lajos a latin eredetű „ordó” kifejezést használja. ${ }^{38}$ Szabó Mihály is él az „ordó” kifejezéssel, de Komáromy és Palágyi az „Orden” magyar megfelelőjeként a „rendjel” lexémát választja.

A társalgásban használt fordulatok, beszédhelyzethez kötött formulák magyarítása is mind a célnyelvi olvasóhoz való igazodást jelzik. Dóczi Lajos Faustja az „Isten hozzád” búcsúszóval köszön el a boldogságtól: „Most Isten hozzád, boldogságom”. A forrásnyelvi szövegben szereplő „Es wird mein schönstes Glück zunichte!” nyersfordításban annyit tesz, mint 'legszebb boldogságom odalesz, megsemmmisül'. Komáromy Andor így fordít: „Egész boldogságomnak vége van!”, Szabó Mihály pedig a következőképpen: „Oda most legszebb szerencsém”.

Faust átlátja, hogy „az ördög egoista, / Egy Isten áldjon-ért nem teszi ő / Azt, miből másnak haszna nő”. A német szövegben „um Gottes willen” szerepel,'az istenért,

38 Tótfalusi István: Idegenszó-tár. Tinta, Bp., 2008. 678. 
az Isten szerelméért' (,... der Teufel ist ein Egoist/ Und tut nicht leicht um Gottes willen, / Was einem andern nützlich ist"). Ha Dóczi kortársainak megoldásait vizsgáljuk, látható, hogy ketten is az „isten nevében” szókapcsolattal élnek (Szabó: „Az ördög egoista, / S isten nevében olyant nem tesz”, Palágyi: „nem segít csak úgy isten nevében”). Ettől némileg eltér Komáromy Andor fordítása: „az ördög önző jól tudom, / S Isten fizessért nem könnyen teszi”.

Mefisztó alázatosan, esedezve kéri az ôt fogva tartó Faustot, hogy bocsássa el: „Ezúttal főkép s mindenképen/ Csak azt instálom, hogy bocsáss”. A népies, régies igei alak, az „instálom” az alázatosság és az udvariasság árnyalatát kölcsönzi Mefisztó kérésének, mint a német eredetiben elhangzó 'kérve kérlek' („Doch jetzo bitt ich, hoch und höchst”). Palágyi a könyörgést a „sürgetô” melléknév fokozó ismétlésével éri el - az alapfokot a középfok követi módhatározói funkcióban: „Most csak azt kérem, sürgetően, / Legsürgetőbben: hagyj, eressz el!”. Komáromy az ismételt „nagyon” határozószóval („Most csak arra kérlek, nagyon, nagyon, / Ereszsz engem ezuttal szabadon”) nyomatékosít, Szabó ördöge pedig megalázkodik Faust előtt: „Most csak arra kérlek, tisztelettel, / S alázatosan, hogy bocsáss el”.

Úgyszintén udvariasságot fejez ki a „de ne vegye zokon” betoldás a Tanítvány beszédében, hiszen az idiomatikus kifejezés a forrásnyelvi szövegben nincs jelen: „De ne vegye zokon: / Megvallom, már is elkivánkozom” („Aufrichtig, möchte schon wieder fort").

A düh, indulatosság kifejezését szolgálják az enyhébb szitokformák, mint a Dóczi Lajos fordításában szereplő „patvarba!”(„Was Henker!”), amely Komáromynál „mit a poklok!”, Palágyinál „teringettét!” felkiáltás lesz.

A „verné el a jég” (Csak hogy kószálni szeretett felette, / meg más borát és hitvesét szerette, / Meg a koczkát - hogy verné el a jég!) Dóczi Lajos célnyelvi szövegében betoldás, hiszen az eredetiben nincsen szitok („Er liebte nur das allzuviele Wandern/ Und fremde Weiber und fremden Wein/ Und das verfluchte Würfelspiel”). A vele kortárs fordítók közül egyik sem told be szitkot, Szabó Mihály az „istenverte kocka” szókapcsolattal él, Palágyi Lajos és Komáromy Andor a forrásnyelvi szöveghez hủen az ,átkos koczka”, valamint az „átkozott sok koczka” kifejezést választják (verflucht - átkozott). A „verné el a jég” betoldás egyfajta kompenzálásként értelmezhető.

Összegzésként elmondható, Dóczi Lajos Goethe múvét úgy fordítja magyarra, hogy rendszerint kellő mértékben és indokolt esetben él a pragmatikai adaptáció lehetőségével. Erre utal az a tény, hogy a későbbi magyar Faust-fordítók többnyire ugyanazokon a szöveghelyeken alkalmaznak adaptációt. A beszélő személynevek magyarításában Dóczi Lajos általában fordítói leleményességről tesz tanúságot, fordítói megoldásai gyakran kifejezőek, szemléletesek. Nemcsak a tulajdonnevek esetében magyarosít, hanem köszönések és társalgásban használt fordulatok, beszédhelyzethez kötött formulák népies változatainak alkalmazásával is. Nála az adaptáció nem mechanikus eljárás, nem él vele indokolatlanul, hanem a célnyelvi olvasóra akar 
hatni vele. A befogadó közösség korabeli elvárásaihoz igazodik, és, ha szükségesnek érzi, akár az idegenítés alkalmazásával teremt sajátos atmoszférát, amint ezt a szellemek német nevének megőrzése mutatja. Ugyanakkor elmondható, hogy a honosítást csak annyiban érvényesíti, amennyiben a mú világa és az általa követett hűségkoncepció követelménye ezt lehetővé teszi. Láthatjuk, hogy fordítói döntései során mindkét fordítói magatartartás - a honosítás és idegenítés - megnyilvánul. A felsorolt fordítói megoldások elemzése azt mutatja, hogy Dóczi Lajos előnyben részesíti a honosítást, a célnyelvi befogadót tartva szem előtt. Kulturális adaptációja az újrafordítási hipotézis elméletével is magyarázható, amely szerint az idegen kultúra befogadása érdekében az első fordításokra a honosítási szándék nagyobb mértékben jellemző.

\title{
THE FORMS OF ADAPTATION IN THE HUNGARIAN TRANSLATION OF FAUST BY LAJOS DÓCZI
}

\author{
Keywords: Lajos Dóczi as a bilingual translator; literary translation; Faust by Johann \\ Wolfgang von Goethe; comparative analyses; culturally bounded words
}

Lajos Dóczi (1845-1919) was a writer, poet and translator, journalist and a bilingual diplomat of Jewish origin. The article describes the translation techniques concerning the culturally bounded words and expressions in the Hungarian translations of Faust written by J. W. Goethe. Analysing the translating techniques and methods applied by Dóczi, the adaption is an outstanding procedure. In the target language text of the drama, in some cases, one can observe the replacement of social-cultural realities of the original text with the elements of the target language culture. Thus, the scene Walpurgis Night is placed form Brocken Mountain to Gellért Hill, in Budapest. Adaption is present especially in the case of geographical and personal names with stylistic value, as well as in the translation of connotative and emotive expressions.

\section{FORMELE ADAPTĂRII ÎN TRADUCEREA ÎN MAGHIARĂ A OPEREI FAUST DE CĂTRE LAJOS DÓCZI}

\section{Cuvinte-cheie: Lajos Dóczi traducător bilingv; traducere literară; Faust de Johann Wolfgang von Goethe; analiză comparativ-contrastivă; realii și cultureme}

Lajos Dóczi (1845-1919) a fost un scriitor, poet, traducător, journalist și diplomat bilingv de origine evreiască. Articolul studiază procedeele de traducere a realiilor, a culturemelor germane în limba maghiară în opera Faust de J. W. Goethe. Privitor la metodele și tehnicile 
abordate de Lajos Dóczi, se constată că unul dintre principiile la care apelează este adaptarea. În textul țintă al dramei observăm înlocuirea unor realități socio-culturale din limba sursă printr-una specifică socioculturii limbii țintă: astfel scena Nopții Walpurgis este mutată de pe muntele Brocken pe Muntele Gellért. Adaptarea se efectuează în cazul unor nume geografice și cel al unor nume de persone având funcție stilistică, dar și a unor expresii cărora li se pot atașa sensuri conotative, asociative sau emotive. 